\title{
The value of a person in Akan traditional life and thought: A contemporary inquiry
}

\author{
PhD. Cand. Joseph Kofi Antwi
}

\begin{abstract}
As a contribution to the debate on African Philosophy, this paper explores the value of a person in Akan traditional life and thought. African philosophy can be found in the various traditional and cultural schemes of the people. This paper maintains that one of the approaches of appreciating African philosophy is through the traditional concept and worldview of the nature of a person. This paper argues that a person is not just a bag of flesh and bones that we see with our eyes, but, a more complex being with soul and body. Through a qualitative analysis of the relevant literature, this paper argues that some contemporary incidents, such as African crossing the Mediterranean Sea to seek better life in Europe, and the recent Xenophobic attacks on some African nationals in South Africa, undermines the indigenous value of a person in Akan traditional life and thought. This paper concludes that the real goal of the value of human life, as one of the dominant themes in African philosophy, must be properly studied, assessed, understood and harnessed in addressing contemporary African problems, such as corruption in government and society, environmental degradation, indiscipline, diseases and conflicts in our communities and other social vices.
\end{abstract}

Keywords: Akan worldview, philosophical thought, communalism, humanism, Agenda 2063

\section{Introduction}

The understanding of a person refers to beliefs and perceptions that Akans have of a person as an individual. A person in the Akan worldview is the basis, centre and end of everything. All other things only make sense in relation to persons. Regardless of their social status, gender or race, persons are recognised, accepted, valued and respected for their own sake. The value of the person is of deep concern to the Akan people in particular and Africans in general, to the extent that it forms part of the themes in African philosophy. Akans recognize the dignity of the person and as such hold a deep and insistent anxiety for human welfare and happiness. ${ }^{1}$ In African culture for example, the deep concern for the value of human dignity is reflected in indigenous African philosophical thoughts, actions, art forms, institutions and is intrinsically linked with all people whether or not they are biologically related. This deep concern for human welfare is manifested in such communal social structures as the clan, the extended family, the whole community, and the nation. ${ }^{2}$

\section{The Akan of Ghana}

Akan is one of the principal tribes in West Africa, inhabiting Ghana, Cote D'Ivoire, some parts of West Africa that speak the Twi language. ${ }^{3}$ The best-known representatives of the tribe are the Asante, Fante, Akyem, Akuapem, Assin, Kwawu, and several of the present Twi speaking races of [modern] Ghana and Cote D'Ivoire. ${ }^{4}$ They are the largest tribal group in Ghana occupying five of the ten administrative regions of the country. According to the 2010 Ghana National Population Census, 47. $5 \%$ of the national population of Ghana are from the Akan ethnic group. ${ }^{5}$ According to Ekem, the geographical location of these Akan-speaking groups is conducive to farming, hunting, and fishing. ${ }^{6}$ They have in common many political, social, religious, and cultural institutions, though there are local variations.

\footnotetext{
${ }^{1}$ Kwame Gyekye, African Cultural Values: An Introduction. (Accra: Sankofa Publishing Company, 2003): 23 ${ }^{2}$ Gyekye, African Cultural Values, 23

3John David Kwamena Ekem. Priesthood in Context (Accra: Sonlife Press, 2009): 27

4 Joseph Boakye Danquah. The Akan Doctrine of God (London: Frank Cass and Company Limited Education, 1968): 198-199

5"2010 Population and Housing Census: Ghana Statistical Service." Available at:

http://www.statsghana.gov.gh/docfiles/2010phc/Census2010_Summary.pdf. (Accessed 12th March 2013)

${ }^{6}$ Ekem, Priesthood in Context, 28
} 
Akan societies are mainly matrilineal and exogamous in their social set-up: inheritance and succession to ranks are usually traced through the mother's lineage, and marriage is not normally permitted between members of the same kin group. ${ }^{1}$ On his part, Noel Smith believes that the basis of Akan society is religious, and the foundation of Akan religion is social. He continues to argue that the completely political and social organisation is inextricably interlocked with religion, and at its heart is the abusua, (the clan), or kindred group. ${ }^{2}$ The abusua is the smallest social unit that comprises the man, his wife, or wives of a different abusua from their husband and their children. This further grows to become the extended family. The abusua includes not only the living, but also the dead and the generation yet unborn. ${ }^{3}$

\section{Theoretical Framework}

The theoretical framework that underpins this paper is borrowed from Kwame Gyekye's social theory of humanism. The concern for human welfare constitutes the hub of the Akan axiological wheel. ${ }^{4}$ This orientation takes its impulse from the humanistic outlook that characterises Akan traditional life and thought. The theory of humanism sees human needs, interest, and dignity as fundamental to the building up of every society. It insists that the good of all determines the good of each. It is therefore expected that every member of the society will work for the good of all, which also takes into account the individual good. In Akan worldview all beings in the universe are interrelated and interconnected to such an extent that the flourishing of one is a function of the flourishing of others. Thus the welfare and interest of each member of society can hardly be accomplished outside the communal system. ${ }^{5}$ The value of person in Akan traditional life and thought this thus better explained through the lens of Akan humanism.

\section{Methods}

There are two approaches to the study of the concept of a person in Akan philosophy. One is ontological or descriptive and the other normative or the social. The descriptive concept of a person in Akan philosophical thinking examines the constituent parts-physical and non-physical-of the human person and their functions or significance in the scheme of things. Wingo Ajume maintains that it is a concept that informs a variety of social institutions, practices, and judgments about personal identity, dignity, moral responsibility, and the proper relationship both among individuals and between individuals and community. ${ }^{6}$ The concept of the person seems to be one of the widely debated ideas in African philosophy. Various thinkers have adopted irreconcilable differences in articulating this concept. This has led to the rise of different schools of thought.

The basic worldview of the person is more or less the same among all the ethnic and religious groups in Africa. In African worldview, the person or individual is not just a bag of flesh and bones that we see, but is made up of something additional to the body that we do not see. ${ }^{7}$ The person is seen as God's creation and is believed to be a biological as well as a spiritual being. In an attempt to understand the value of a person in Akan traditional life and thought, I shall be examining the views of three major Akan philosophers: Kwasi Wiredu, Kwame Gyekye and Kwasi Appiah. These philosophical thinkers present very different accounts of the same concept, particularly with respect to the relationship between social recognition and innate characteristics to the person.

Examining the value of a person in Akan traditional life and thought from these different perspectives highlights both the richness of the conception. It also highlights four contrasting views from Western philosophy. These are:

the continuous nature of the person,

the means by which individuals achieve full status as a person,

1Ekem, Priesthood in Context, 8

2 Noel Smith, The Presbyterian Church of Ghana: 1835-1960 (Accra: Ghana University Press, 1966): 65

${ }^{3}$ Robert S. Rattray, Ashanti (Oxford: Clarendon Press, 1923): 35, 77

${ }^{4}$ Kwame Gyekye, An Essay on African Philosophical Thought: the Akan Conceptual Scheme. (Philadelphia: Temple University Press, 1987): 143

${ }^{5}$ Gyekye, An Essay on African Philosophical Thought, 155

6Wingo, Ajume, "Akan Philosophy of the Person", in The Stanford Encyclopedia of Philosophy (Fall 2008 Edition). Edited by Edward N.

Zalta. Available at: URL = <http://plato.stanford.edu/archives/fall2008/entries/akan-person/ (Accessed 4th May, 2015)

${ }^{7}$ Gyekye, An Essay on African Philosophical Thought, 85 
the implications of this conception of personhood for the relationship between individuals and the community,

and lastly the Akan understanding of responsibility and freedom.

\section{Results/Discussion}

In some philosophical, sociological and anthropological accounts, the nature of a person gives the impression of a tripartite conception, which is the soul Okra, (spirit) Sunsum and Honam (body). Kwasi Wiredu upholds a pentachotomistic view of a person in the Akan culture. He states that the okra is the life principle and source of human dignity and destiny. The Sunsum is the personality principle of the person, the Mogya (blood) is the kinship principle, the Nipadua (the physical body) and the Ntoro, that which is responsible for the cast of personality. The Ntoro (the semen) is inherited from one's father and is taken as the basis of membership of a patrilineal group. ${ }^{1}$

Kwame Gyekye on the other hand believes that the Akan conception of a person is dualistic: that is Okra (soul) and Honam (body), but not tripartite: ${ }^{2} \mathrm{He}$ observes that, the okra (soul) and the Sunsum (spirit) are the immaterial (spiritual) part of the person, and the Honam (body) is the material (physical) part of the body.

Wiredu is however quick to warn against the translation of okra to the English "soul. "3 He maintains that the okra is "that whose presence in the body means life and whose absence means death and which also received the individual's destiny from God. "4 Contrasting between the "soul" and the Okra, Wiredu believes that the "soul" is supposed in Western philosophy to be a purely immaterial entity that somehow inhabits the body, the Okra, on the other hand, is quasi-physical substance and having a "para-physical properties. "5 This is because the Akan believe that "highly developed medicine men" with extrasensory (or medicinally heightened) perceptions are capable of seeing and communicating with the Okra. Gyekye contends this argument and notes that these phenomena do not take place in the ordinary spatial world: otherwise anyone would be able to see or communicate with the Okra (soul). ${ }^{6}$ In his opinion, the ability to see the Okra is not at the physical or spatial level.

Another Akan philosopher, Kwame Appiah, perhaps, offers a clearer summary of the Akan concept of a person in his tripartite analysis. He writes among others that:

A person consists of a body (Nipadua) made from the blood of the mother (the mogya) ; an individual spirit, the Sunsum, which is the main bearer of one's personality; and a third entity, the okra. The Sunsum derives from the father at conception. The okra, a sort of life force that departs from the body only at the person's last breath; is sometimes as with the Greeks and the Hebrews, identified with breath; and is often said to be sent to a person at birth, as the bearer of one's Nkrabea, or destiny, from Nyame. The Sunsum, unlike the okra, may leave the body during life and does so, for example, in sleep, dreams being thought to be the perceptions of a person's Sunsum on its nightly peregrinations. ${ }^{7}$

I acknowledge the magnitude of these debates on the Akan perception of the person. Despite the various views expressed by the different Akan thinkers; I consider that the most important theme that runs through the various positions is the understanding of the presence of the Okra in man. In my view the Okra is that which constitute the innermost self, the essence, of the individual person. I agree with Gyekye in saying that the Okra is the immaterial or spiritual component of the person, with the Nipadua as the material component. I have examined so far the constituent-parts of the person, in the next section, am focusing on the normative concept of a person as found in Akan philosophical thinking.

\footnotetext{
${ }^{1}$ Kwasi Wiredu, "The Akan Concept of Mind," in Ibadan Journal of Humanistic Studies, no 3 (1983): 119.

${ }^{2}$ Kwame Gyekye, "The Relation of Okra (Soul) and Honam (Body): An Akan Conception." In African Philosophy: An Introduction. Edited

by Emmanuel Chukwudi Eze. 58-66. (Oxford: Blackwell, 1998): 64

3Wiredu, "The Akan Concept of Mind,"119

"Wiredu, "The Akan Concept of Mind," 120

5Wiredu, "The Akan Concept of Mind"119

${ }^{6}$ Gyekye, African Philosophical Thought: the Akan Conceptual Scheme, 86

${ }^{7}$ Kwasi K. Appiah, "Akan and Euro-American Concepts of the Person" in African Philosophy: New and Traditional Perspectives. Edited

by Lee M. Brown. (Oxford: Oxford University Press, 2004): 28
} 


\section{The Making of a person in Akan Culture}

Another approach to the study of the concept of a person in Akan thinking is the social (normative) method. It reveals the social status of the individual. To be a person is not something one is born with, it has a particular significance within the African cultural context. Wiredu maintains that personhood is not an automatic quality of the human individual; it is something to be achieved, the higher the achievement, the higher the credit. ${ }^{1}$ From this perspective, a person is not just any individual, but one who has attained the status of a responsible member of the society.

The individual life does not and cannot exist alone except within a community. The normative concept of a person therefore evolves from the way in which a person is understood in a given community in terms of his relations to other living beings and his role among other men. The Kenyan theologian, John S. Mbiti, in his work African Religions and Philosophy, argues that the individual owns his/her existence to other people, including those of past generations and his contemporaries. ${ }^{2}$ The individual is part of the community, and it is the responsibility of the community to ensure his/her upbringing. The community must make, create, nurture or produce the individual.

Mbiti maintains that physical birth is not enough: the child must go through rites of incorporation so that it becomes fully integrated into the entire society. ${ }^{3}$ Agreeing with Mbiti, Joseph Kofi Antwi writes that the growth of the individual is marked by stages: birth, puberty, marriage, death and life after death. After birth the baby grows through the puberty stage into a young adult and then to adulthood. The adult then marries, brings forth children, grows old, and dies. ${ }^{4}$ In the view of Mbiti, even after death, the person is ritually incorporated into the wider family of both the dead and the living. ${ }^{5}$

In bringing up the individual, it is envisaged that every aspect of the person's being will be fashioned and nurtured. Throughout each stage of the nurturing process, the person is formed "to become. "This is to enable the individual to live an acceptable moral life within the Abusua (family) and be a respected member of the community. Bernard Matolino, argues that in African thinking, the concept of personhood is the sort of thing that one can be better at, worse at, or fail at. ${ }^{6}$

\section{The virtue of human dignity in Akan philosophical thought}

In Akan culture, it is believed that a person has dignity, which makes the person or individual divine and therefore to be respected and valued. This dignity stems from the belief that the individual is created by Onyakopong (Supreme Being). In the Akan worldview, as in all African societies, a person is not "a thing or a number" but something valuable than these. ${ }^{7}$ Whether a person is known or not, respect is expected to be accorded to him or her. Respect for an individual, which is accompanied by acceptable good behaviour, is highly regarded in African culture. Addo Dankwa stresses that Africans are value-minded people. ${ }^{8}$ As such, a person who exhibit great value is preferable. In the view of Gyekye "values are the patterns or principles of conduct that are considered most worthwhile and cherished by a society. "9

The need for respect for value becomes evident when one undermines or ill-treats another person. The Akan maintains that anything that brings disgrace to the value of the person, the family, and the society in general, is said to be an abomination. Society therefore frowns on anything that brings reproach to the person. A person of good moral values is the toast of the society. The Akan believe that such a person is made or nurtured to be, by the community, and not born. Antwi argues that the Akan maxim: Anim guase mfata Okanni Ba, '-"a thing of dishonour and a son of the Akan go ill together,"

\footnotetext{
${ }^{1}$ Kwasi Wiredu, "The African Concept of Personhood," In African-American Perspectives on Biomedical Ethics. Edited by Flack E. Harley and Edmund D. Pellegrino. (Washington, D.C.: Georgetown University Press, 1992):104

2John S. Mbiti, African Religions and Philosophy. (London: Heinemann Publishers 1969: 106

3Mbiti, African Religions and Philosophy, 106.

4Joseph Kofi Antwi. "Integrating Indigenous Akan Educational Patterns into Christian Education in the Presbyterian Church of Ghana." An Unpublished MPhil diss., School of Graduate Studies, Kwame Nkrumah University of Science and Technology, Kumasi, (2011): 95 5 Mbiti, African Religion and Philosophy, 106

6 Bernard Matolino, "The (Mal) Function of "it" in Ifeanyi Menkiti's Normative Account of Person." African Studies Quarterly, Volume 12, Issue 4, 23-37, (2011): 24

${ }^{7}$ Mluleki Michael Ntutuzelo Mnyaka, Xenophobia as a response to Foreigners in Post-Apartheid South Africa and Post-Exilic Israel: A comparative critique in the light of the Gospel and Ubuntu Ethical Principles. An Unpublished Doctor of Philosophy dissertation presented to the University of South Africa, (2003):iii ${ }^{8}$ Dankwa, Addo O. III. Christianity and African Traditional Beliefs. (New York: The Power of the Word Press, 1990): 86-87.

${ }^{9}$ Gyekye, An Essay on African Philosophical Thought, 70,
} 
sums up the whole attitude to morality, dignity, and behaviour. ${ }^{1}$ In other words, an Akan is a person of dignity, one without disgrace in nature. In explaining this maxim, Danquah argues that what made a person of importance, outstanding in the eyes of the society, was the fact that such a person had lived their life as an ordinary citizen and had not lost in dignity or honour and not suffered disgrace, ('animguase, ' 'face descending to basement, ' 'debasement of the person'). He emphasizes that:

As a son of the Akan, he was born with an anim, a positively good Akan, and his success in life consisted in not having fallen below the high degree at his birth, that is to say, in not having allowed his face, presence or countenance, anim (to gu, fall, ase, down) to be lowered. To the noble Akan son, fall from grace is a fall during one's own lifetime... it is a fall within the conscious power of each particular moral subject to avoid. Not to have fallen...is counted to the moral subject a thing of supreme achievement. ${ }^{2}$

For this reason a lot of formal and informal activities are lined up for the Akan, especially the young ones, so that they start their journey towards the older and future lives well prepared, in order to avoid 'animguase'- debasement of personality. The Akan has a maxim that supports this position: "Biribiara nye yaw se aniwu, "- "nothing is more painful than disgrace. "Hans W. Debrunner stresses that in Akan philosophy an immense value is put on ordered Amane (behaviour) and Bra pa (character training). He further indicates that by these a man should prove himself as Wapow (polished) and Okanni (gentlemanlike). ${ }^{3}$ This absence of disgrace, this attainment and maintenance of dignity, makes the moral subject an excellent person. ${ }^{4}$ The person is expected to perform every activity and come up on top without disgrace, or debasement to the dignity. Therefore, any act that affects such dignity is an affront to humanity.

In indigenous Akan philosophical thought for example, the virtue of human dignity is expressed throughout the various human activities. Danquah observes that:

The person had married and been given in marriage with honour; he had been a member of the Asafo or company of fighting men with honour; he had taken wine and dined with men with honour; or enjoyed plenty with honour; brought up children with honour; worshipped at the shrines with honour; he had sowed and reaped with honour; had suffered bereavement with honour; and above all, had joined with others, or acted alone, to settle family and other disputes, bringing peace and increase to the family with honour. ${ }^{5}$

Anybody who goes through these activities, or passed these tests without disgrace is seen as the ideal person. Danquah describes such a person as: "an adult (an Opanyin), a grown up person, a person of rank, an elder. "6 Generally, the African believe that "an adult" is not born but made, or nurtured. An Akan philosophical maxim states that "Obi nhyee da nwoo pinyin pen". ${ }^{7}$ Meaning, no one by design ever gave birth to an adult. Philosophically, the adult is made, nurtured, groomed or discovered. The community makes the person. Such a person becomes the focus by which the young and inexperienced of the family and community are exhorted to measure their conduct. Another Akan maxim puts it plainly as 'Abofra hu ne nsahohoro a, one mpanyinfo didi. "That is a child may dine with his elders if his hands are nice or clean. ${ }^{8}$ In the Akan philosophical thought the standard set by the "adult" is preferred by the community. The Akan will say "Opanyin ano sen suman", that is the word of the elder is more potent than the fetish. ${ }^{9}$

\section{Some contemporary challenges to Human Dignity}

In Akan worldview it is believed that life is the highest gift of God to humanity. Anything that undermines hurts, threatens, brings disgrace and destroys life is not accommodated, but is frowned upon since it affects the very foundation of the entire community. The Akan view about human dignity and the value that is attached to it perhaps derives from the indigenous belief that humanity is a creation of God. This is expressed in the Akan maxim, Nnipa nyinaa ye Onyame mma; obi nye

\footnotetext{
${ }^{1}$ Antwi, Integrating Indigenous Akan Educational Patterns into Christian Education in the Presbyterian Church of Ghana., 54

2 Danquah. The Akan Doctrine of God, 121

${ }^{3}$ Hans W. Debrunner, A History of Christianity in Ghana. (Accra: Waterville Publishing House, 1967): 2

4Danquah, The Akan Doctrine of God, 122
}

5Danquah, The Akan Doctrine of God, 122

'Danquah, The Akan Doctrine of God , 122

7Danquah, The Akan Doctrine of God, 188

8Danquah, The Akan Doctrine of God, 189

'Danquah, The Akan Doctrine of God, 194 
asaseba. This means all men are the offspring of God; no one is the offspring of Earth. ${ }^{1}$ Another maxim indicates Onipa na oma onipa ye yiye, that is the beneficence of man depends upon man. These and other such indigenous philosophical thoughts indicate how the African value human life. However, recent happenings around the world, especially, in some parts of Africa raise concerns that are affront to the concept of human dignity in Africa.

One of such situations the exodus of some young Africans crossing the Mediterranean Sea for better life in Europe. The deadly voyage across the Mediterranean Sea into Europe is often the last resort for many desperate Africans. Most of the victims were from poor families from almost every country in West Africa. According to the United Nations, 2016 has been the deadliest year for African migrants bound for Europe. UNHCR reported that 3, 740 lives had been lost so far in 2016, just short of the 3,771 reported for the whole of 2015. ${ }^{2}$ The number keeps on increasing by the day. Human lives being wasted on the road to better life opportunities.

The other situation is the xenophobia attacks on African immigrants in post-apartheid South Africa. Earlier in 2015, some disgruntled black South Africans targeted foreigners, mainly Zimbabweans, Somalis, Nigerians and Pakistanis, accusing them of stealing jobs and opportunities in Durban, KwaZulu-Natal province and in Grahamstown, Eastern Cape. At least five (5) people were killed, thousands displaced, prompting the country to deployed its army to help police curb the violence. ${ }^{3}$ These disgruntled black South Africans have sacrificed the principles such as human dignity, human rights, reciprocity, love, compassion, and community in their dealings with foreigners. ${ }^{4}$ These attacks received international condemnations, with the Christian Council of Ghana describing them as ungodly, unwarranted and barbaric, which has led to scores of deaths and loss of properties. ${ }^{5}$

\section{Reconstructing a new African through Agenda 2063}

These, and many more dehumanising situations, such as tribal conflicts, politically-related violence, and famine (are extremely worrying, especially at a time when Africans are seeking to have an integrated, united, sovereign, independent, confident and self-reliant continent through "The Africa We-Want-Agenda 2063" which is currently being championed by the African Union (AU). ${ }^{6}$

This agenda talks about how the continent of Africa should effectively learn from the lessons of the past, build on the progress now underway and strategically exploit all possible opportunities available in the short, medium and long term, so as to ensure positive socioeconomic transformation within the next 50 years. This is a people-driven agenda that involves every African irrespective of race, colour, gender, language or religion. From this agenda it is discernable that Africans are conscious of the fact that they have a common humanity, which has a certain dignity, integrity and value that needs to be acknowledged, respected and valued: and that no one has superior or inferior humanity.

\section{An appeal to communalism}

In an attempt to finding a solution to these and other social problems facing Africa, an appeal must be made to Akan traditional and living philosophy of communalism. Communalism, as defined by Gyekye, is the doctrine that the group or society constitutes the focus of the activities of the individual members of the society. ${ }^{7}$ As a social construct, communalism insists that the good of all determines the good of each. It is therefore expected that every member of the society will work for the good of all, which also takes into account the individual good.

In Southern Africa this philosophy of communalism is known as Ubuntu/botho: that is "a person is a person through other persons. "Allister Sparks believes that this expression is in the African psyche and helps to diffuse the individual ego and

\footnotetext{
1Danquah, The Akan Doctrine of God, 193

2 William Spindler, UN High Commissioner for Refugees. Available at: http://www.unhcr.org/enus/news/latest/2016/10/580f3e684/mediterranean-death-toll-soars-2016-deadliest-year.html.(Accessed on 21st Dec., 2016)

${ }^{3}$ Available at: http://www.ibtimes.co.uk/south-africa-xenophobic-attacks-target-foreign-owned-shops/ (Accessed on 21st Dec.,2016) ${ }^{4}$ Mluleki Michael Ntutuzelo Mnyaka, Xenophobia as a response to Foreigners in Post-Apartheid South Africa, iii

${ }^{5}$ Kwabena Opuni-Frimpong. Available at:

http://www.christiancouncilgh.org/XENOPHOBIC\%20ATTACK\%20IN\%20SOUTH\%20AFRICA\%20UNGODLY.pdf. (Accessed on 29th April 2015)

${ }^{6}$ Agenda 2063: The Future we all want. Available at: http://agenda2063.au.int/. (Accessed on 29th April 2015).

${ }^{7}$ Gyekye.An Essay on African Philosophical Thought: the Akan Conceptual Scheme,155
} 
makes Africans less prone to acts which do not contribute to community building. ${ }^{1}$ It is this feature that distinguishes a person from other creatures. Writing on "Person and Community in African Traditional Thought', Ifeanyi A. Menkiti asserts that in African thought the reality of the communal world takes precedence over the reality of the individual life histories. ${ }^{2}$ Generally, many African thinkers subscribe to the view that communism, rather than individualism, is the accepted principle around which all other facts revolve.

I believe that an understanding and implementation of the principles and values of communalism/Ubuntu can challenge and inspire others to view and treat African immigrants differently irrespective of where they are. Gyekye points out that the divine nature in humanity constitutes all persons into one universal family of humankind. ${ }^{3}$ The concept of communalism advocates for values such as sharing, mutual aid, caring for others, interdependence, solidarity, reciprocal obligation, social harmony and success of the wider society rather than, but not at the expense of, the individual. Mbiti for example, believes that the individual has little latitude for self-determination outside the context of the traditional African family and community. He writes:

"Whatever happens to the individual happens to the whole group, and whatever happens to the whole group happens to the individual. The individual can only say: 'I am, because we are; and since we are, therefore I am. ' This is a cardinal point in the understanding of the African view of man" 4

Aristotle proclaimed many centuries ago that man is by nature a social animal, and that it is impossible for him to live outside society. ${ }^{5}$ The Akan traditional life and thought agrees with this assertion and maintains that the society as a necessary condition for human existence. This philosophical idea is expressed in the maxim "Onipa firi soro na obesi a, obesi nnipa kuro so" that is to say, if even a man alights on earth from heaven, he alights in a habitation of men. ${ }^{6}$ This indigenous thought sees humans as originally born into a human society (Nnipa krom), and therefore as social beings. It is therefore anti-social for people to live in isolation, or in solitary life. The anti-apartheid activist, Steve Biko, supports this African philosophical thought in his article "Some African Cultural Concepts. " He writes:

We believe in the inherent goodness of man. We enjoy man for himself. We regard our living together not as an unfortunate mishap warranting endless competition among us but, as a deliberate act of God to make us a community of brothers and sisters jointly involved in the quest for a composite answer to the varied problems of life. Hence in all we do, we always place Man first and hence all our action is usually joint community oriented action rather than the individualism which is the hallmark of the capitalist approach. ${ }^{7}$

In African culture, human relations are highly valued; as such they accord respect and care for strangers irrespective of their racial or ethnic background. This African idea of communalism or brotherhood 8 is again expressed in the Akan maxim "Nnipanua ne nnipa, " meaning Man's brother is man. To the Akan, humanity is related, constituting into one universal human family. These Akan maxims and many others similar in content, underscore the need to appreciate the value of a person in African culture.

James E Lassiter, quoting Senegalese philosopher Leopold Senghor, regards indigenous African society to be "based both on the community and on the person and which, because it was founded on dialogue and reciprocity, the group had priority over the individual without crushing him, but allowing him to blossom as a person. "9 Buttressing the importance of community and the value of human life in African culture, Steve Biko, notes:

\footnotetext{
${ }^{1}$ Allister.Sparks. The mind of South Africa. (New York: Heinemann, 1990): 249

2. A. Menkiti, "Person and Community in African Traditional Thought." In African Philosophy: an Introduction. Edited by Richard. A. Wright. (Washington: University Press of America, 1984): 171

${ }^{3}$ Gyekye, African Cultural Values: an Introduction., 24

${ }^{4}$ Mbiti, African Religions and Philosophy, 106.

${ }^{5}$ Aristotle Politics, (Dover Publications, 2000)

${ }^{6}$ Danquah, The Akan Doctrine of God, 193

7Steve Biko. I Write What I like. Edited by Aelred Stubbs. (Oxford: Heinemann, 1987): 42

${ }^{8}$ Gyekye, African Cultural Values, 26

9 James E Lassiter. African Culture and Personality: Bad Social Science, Effective Social Activism, or a Call to Reinvent Ethnology? 3(2), 1999 (Accessed 27 th August, 2011)
} 
One of the most fundamental aspects of our culture is the importance we attach to Man. Ours has always been a Mancentred society. Westerners have on many occasions been surprised at the capacity we have for talking to each other - not for the sake of arriving at a particular conclusion but merely to enjoy the communication for its own sake. ${ }^{1}$

In an article "Morals and the Value of Human Life" M. M. Agrawal noted that the moral values of a particular society should be seen to interpret to its members, the notion of an ultimate value. ${ }^{2}$ In the view of Agrawal, the collective moral value of the entire community is paramount, and it serves as the regulative principle for the determination of moral values. Individual values are however not suppressed but are expected to fall within the ultimate societal values.

From the foregoing, I can argue that Africa has a philosophy which has its roots in the cultural values of the people. However, such philosophical thoughts and ideas are not found in documents, but in oral traditions and through indigenous institutions. These and many other cultural values and practices of indigenous Akan can be considered positive features that could be accommodated in the scheme of African developmental agenda. I propose that these must undergo some interpretation, elucidation, refinement and pruning to become fully harmonious with the spirit of contemporary needs and if possible to function satisfactorily for Agenda 2063, being advocated by the African Union (AU). ${ }^{3}$

\section{Conclusion}

This paper has examined the value of a person in Akan traditional life and thought. It can conclude that the concept is neither simply descriptive (ontological) nor normative (social) but a combination of both. The Akan concept of a person accommodates a common humanity as an innate source of value, and it also supports moral equality. The concept's emphasis on the social bases of person helps firmly to integrate trust, cooperation, and responsibility to the community. The value of a person in Akan traditional life and thought thus represents an attempt to resolve issues of identity, freedom, and morality in favour of a communalistic way of life.

The paper further concludes that the concept of communalism/brotherhood/Ubuntu is opposed to things that are hurting to a person. That is why the recent xenophobic attacks in South Africa, should engage the attentions of African philosophical thinkers to pursue human-centered agenda that will address livelihoods challenges such as poverty, inequality, unemployment, indiscipline, environmental degradation, (poor health services, access to educational facilities and corruption, which greatly affects Africans. African philosophers must reject anything that destroys the most cherished of our beliefs: human life, which is the corner-stone of African society, and with all his ramifications. The great powers of the world may have done wonders in giving the world advance form of science and technology, but that special contribution that has to come from African culture will be in the field of human relationship. This will give the world a more human face.

\section{REFERENCE LIST}

[1] Agenda 2063: The Future we all want. Available at: http://agenda2063. au. int/. Accessed

[2] on 29th April 2015

[3] African Cultural Values: An Introduction. Accra: Sankofa Publishing Company, 2003

[4] Agrawal, M. M. "Morals and the Value of Human Life. "In African Philosophy: an Introduction. Edited by Emmanuel Chukwudi Eze. 146-154. Oxford: Blackwell, 1998

[5] Ajume, Wingo, "Akan Philosophy of the Person", in The Stanford Encyclopedia of Philosophy (Fall 2008 Edition). Edited by Edward N. Zalta. Available at: URL $=<$ http://plato. stanford. edu/archives/fall2008/entries/akan-person/. Accessed 4th May, 2015

[6] Antwi, Joseph Kofi. "Integrating Indigenous Akan Educational Patterns into Christian Education in the Presbyterian Church of Ghana. "An Unpublished MPhil diss. , School of Graduate Studies, Kwame Nkrumah University of Science and Technology, Kumasi, 2011

\footnotetext{
'Steve Biko, I Write What I like, 41

2M. M. Agrawal. "Morals and the Value of Human Life."In African Philosophy: an Introduction. Edited by Emmanuel Chukwudi Eze. 146154. (Oxford: Blackwell, 1998): 146

${ }^{3}$ Agenda 2063: The Future we all want. Available at: http://agenda2063.au.int/.(accessed on 29th April 2015).
} 
[7] Appiah, Kwasi K. "Akan and Euro-American Concepts of the Person" in African Philosophy: New and Traditional Perspectives. Edited by Lee M. Brown. Oxford: Oxford University Press, 2004

[8] Aristotle Politics, Dover Publications, 2000

[9] Biko, Steve. I Write What I like. Edited by Aelred Stubbs. Oxford: Heinemann, 1987

[10] Dankwa, Addo O. III. Christianity and African Traditional Beliefs. New York: The Power of the Word Press, 1990

[11] Danquah, Joseph Boakye. The Akan Doctrine of God. London: Frank Cass and

[12] Company Limited Education, 1968)

[13] Debrunner, Hans W. A History of Christianity in Ghana. Accra: Waterville Publishing House, 1967

[14] Ekem, John David Kwamena. Priesthood in Context. Accra: Sonlife Press, 2009

[15] Ghana Statistical Service, 2010 Population and Housing Census. Available at:

[16] http://www. statsghana. gov. gh/docfiles/2010phc/Census2010_Summary pdf. Accessed 12th March 2013

[17] Gyekye, Kwame. An Essay on African Philosophical Thought: the Akan Conceptual Scheme. Philadelphia: Temple University Press, 1987 "The Relation of Okra (Soul) and Honam (Body) : An Akan Conception. "In African Philosophy: An Introduction. Edited by Emmanuel Chukwudi Eze. 58-66. Oxford: Blackwell, 1998

[18] Lassiter. James E. African Culture and Personality: Bad Social Science, Effective Social Activism, or a Call to Reinvent Ethnology? 3 (2), 1999. Accessed (27 th August, 2011.

[19] Matolino, Bernard. "The (Mal) Function of "it" in Ifeanyi Menkiti's Normative Account of Person. " African Studies Quarterly, Volume 12, Issue 4, 23-37, 2011 (

[20] Mbiti, John S. African Religions and Philosophy. London: Heinemann Publishers 1969

[21] Menkiti, I. A. "Person and Community in African Traditional Thought. "In African Philosophy: an Introduction. Edited by Richard. A. Wright. Washington: University Press of America, 1984

[22] Mnyaka, Mluleki Michael Ntutuzelo. Xenophobia as a response to Foreigners in Post-Apartheid South Africa and Post-Exilic Israel: A comparative critique in the light of the Gospel and Ubuntu Ethical Principles. An Unpublished Doctor of Philosophy dissertation presented to the University of South Africa, 2003.

[23] Opuni-Frimpong, Kwabena. Available at: http://www.christiancouncilgh. org/xenophobic\%20attack\%20in\%20south\%20africa\%20ungodly. pdf. Accessed on 29th April 2015

[24] Rattray, Robert S. Ashanti. Oxford: Clarendon Press, 1923

[25] Smith, Noel. The Presbyterian Church of Ghana: 1835-1960. Accra: Ghana University

[26] Press, 1966

[27] Sparks, Allister. The mind of South Africa. New York: Heinemann, 1990

[28] Spindler, William. UN High Commissioner for Refugees. Available at:

[29] http://www. unhcr. org/en-us/news/latest/2016/10/580f3e684/mediterranean-death-toll-soars-2016-deadliestyear. html. Accessed on 21st Dec. , 2016

[30] Wiredu, Kwasi. "The Akan Concept of Mind, " in Ibadan Journal of Humanistic Studies,

[31] no 3. 1983

[32] The African Concept of Personhood, "In African-American Perspectives on Biomedical Ethics. Edited by Flack E. Harley and Edmund D. Pellegrino. Washington, D. C. : Georgetown University Press, 1992 http://www. ibtimes. co. uk/south-africa-xenophobic-attacks-target-foreign-owned-shops/ (Accessed on 21 ${ }^{\text {st }}$ Dec. , 2016) 